\title{
TAXONOMY OF THE BRACHYCOME LINEARILOBA COMPLEX (ASTERACEAE)
}

\author{
C. R. CARTER*
}

(Accepted 2.2.1978)

\begin{abstract}
Carter, C. R. (School of Biological Sciences, University of Sydney, N.S.W., Australia 2006) 1978. Taxonomy of the Brachycome lineariloba complex (Asteraceae). Telopea 1 (5): 387-393.Previously published results of extensive cytological studies are supplemented by morphological evidence to provide the basis of a revised classification of the Brachycome lineariloba complex. The newly described taxa are $B$. breviscapis C. R. Carter, B. dichromosomatica C. R. Carter and B. dichromosomatica var. alba C. R. Carter. B. lineariloba (DC.) Druce, as circumscribed here, includes three cytodemes $(\mathrm{B}, 2 n=12 ; \mathrm{C}, 2 n=16$; and $\mathrm{E}$, somatic no.. $=10$ ).
\end{abstract}

\section{INTRODUCTION}

The most recent treatment of Brachycome $\dagger$ is by Gwenda L. Davis (1948). She observed a large variation in the size of the plants of $B$. lineariloba (DC.) Druce, noting that some fruiting plants were only $20 \mathrm{~mm}$ high. Davis also noted a discontinuity in the variation of the length of the ray florets, but could not correlate this with any other character. She attributed the variation in the lobing of the leaves to the length of the growing period and concluded that "It is not considered desirable to erect a new variety until further specimens are forthcoming".

Since then a great deal of work has been done on the cytology of this complex. The terms "chromosome species", "chromosome race" and "race" have been used in previous publications, and are used here in quotation marks when referring to previously published data. This usage probably reflected some uncertainty about the deserved taxonomic status of these entities at the time. I shall use cytodeme or deme (cytogamodemes, sensu Gilmore and Heslop-Harrison, 1954) to refer to these entities, except where formal taxonomic status is conferred. Smith-White (1968) reported three different chromosome numbers in this species. Later Smith-White and Carter (1970) reported a total of five "chromosome species" in the complex to which they referred as: $\mathrm{A}(2 n=4), \mathrm{B}(2 n=12), \mathrm{C}(2 n=16), \mathrm{D}(2 n=8)$ and $\mathrm{E}$ (somatic number 10, forms four bivalents and two univalents at meiotic first metaphase). They also gave brief descriptions of the five "chromosome species" but did not attempt to define discriminatory characters or revise the taxonomy.

Kyhos, Carter and Smith-White (1977) have since proposed a detailed phylogenetic scheme for the five "chromosome races" based on several features: the number, morphology and behaviour of the chromosomes; meiotic analysis of hybrid plants; plant size and vigour; and ecogeographical considerations. The

* School of Biological Sciences, University of Sydney, N.S.W., Australia 2006.

$\dagger$ Eichler (1965, p. 297) suggests that Cassini should not have changed Brachyscome to Brachycome, and uses the former name. All the other papers cited here which refer to the species, have used the name Brachycome, and this paper will continue that familiar usage. 
scheme proposed is unique and rather complex, but does not involve a polyploid series. On the basis of the evidence, "races" A and D are deserving of separate specific status.

"Races" B, C and E cannot be distinguished morphologically (even from living material) by any character other than chromosome number, although there is an increase in average size from $\mathrm{E}$ (the smallest) to $\mathrm{B}$ and $\mathrm{C}$. There is, however, considerable overlap in size, and it cannot be used to discriminate effectively between the three "races" which are treated as belonging to one species.

For cytogenetic purposes they may be distinguished as cytodemes. Because they have already been used in several publications, the letters B, C and E should be retained to denote these cytodemes. A microfiche photograph of the lectotype of $B$. lineariloba has been examined. The decumbent to ascending growth habit and the locality of collection both indicate that it must belong to one of the B, C or E cytodemes. Therefore the specific epithet lineariloba must remain with these cytodemes.

Race A has also been divided into four cytodemes on the basis of chromosome morphology (Watanabe, Carter and Smith-White, 1975). One of the these $\left(\mathrm{A}_{3}\right)$ is deserving of varietal status as it is geographically disjunct and morphologically distinct, having pure white ray florets, as opposed to pale-blue in the other three cytodemes. The small chromosomal differences (all have the same number, $n=2$ ) and adjoining geographical distributions of demes 1,2 and 4 are treated in detail by Watanabe et al., but are not considered to be of taxonomic importance.

All specimens cited are collected by S. Smith-White and C. R. Carter and are located in SYD. This departs from the usual practice of examining material from several herbaria, which I have been unable to do. However the collection at SYD contains more than 1000 specimens of this complex, and all those cited have been determined chromosomally. Most of the known range of the complex has been searched and sampled over a period of ten years. Thus the distributions given, although based only on SYD specimens, represent an accurate picture of the ranges of the species. It is at least as extensive as that given by Davis (1948) which was based on specimens from several herbaria. Specimens determined under the revised taxonomy will be donated to the major herbaria in Australia. Locations given for all specimens are listed approximately east to west. The distributions of the species and cytodemes are given in Map 1.

\section{KEY TO THE BRACHYCOME LINEARILOBA COMPLEX}

1. Scapes erect, $30-250 \mathrm{~mm}$ long. Ligules $5-12 \mathrm{~mm}$ long, pale-blue or white. Margins of involucral bracts not usually pigmented, rarely reddish-purple . . B. dichromosomatica 2.

2. Ligules pale-blue, at least on the undersides .......... var. dichromosomatica a.

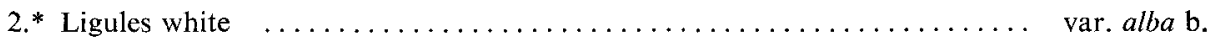

$1{ }^{*}$ Scapes decumbent to ascending, 1-200 mm long. Ligules up to $6 \mathrm{~mm}$ long, white. Margins of involucral bracts usually reddish-purple.

3. Scapes 1-20 mm long, first-formed scape less than $10 \mathrm{~mm}$ long. Ligules less than

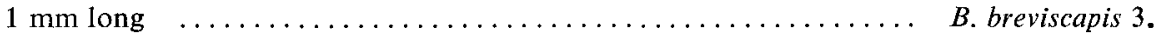

3.* Scapes $10-200 \mathrm{~mm}$ long, first-formed scape more than $10 \mathrm{~mm}$ long. Ligules $1-6 \mathrm{~mm}$ long B. lineariloba 1 . 


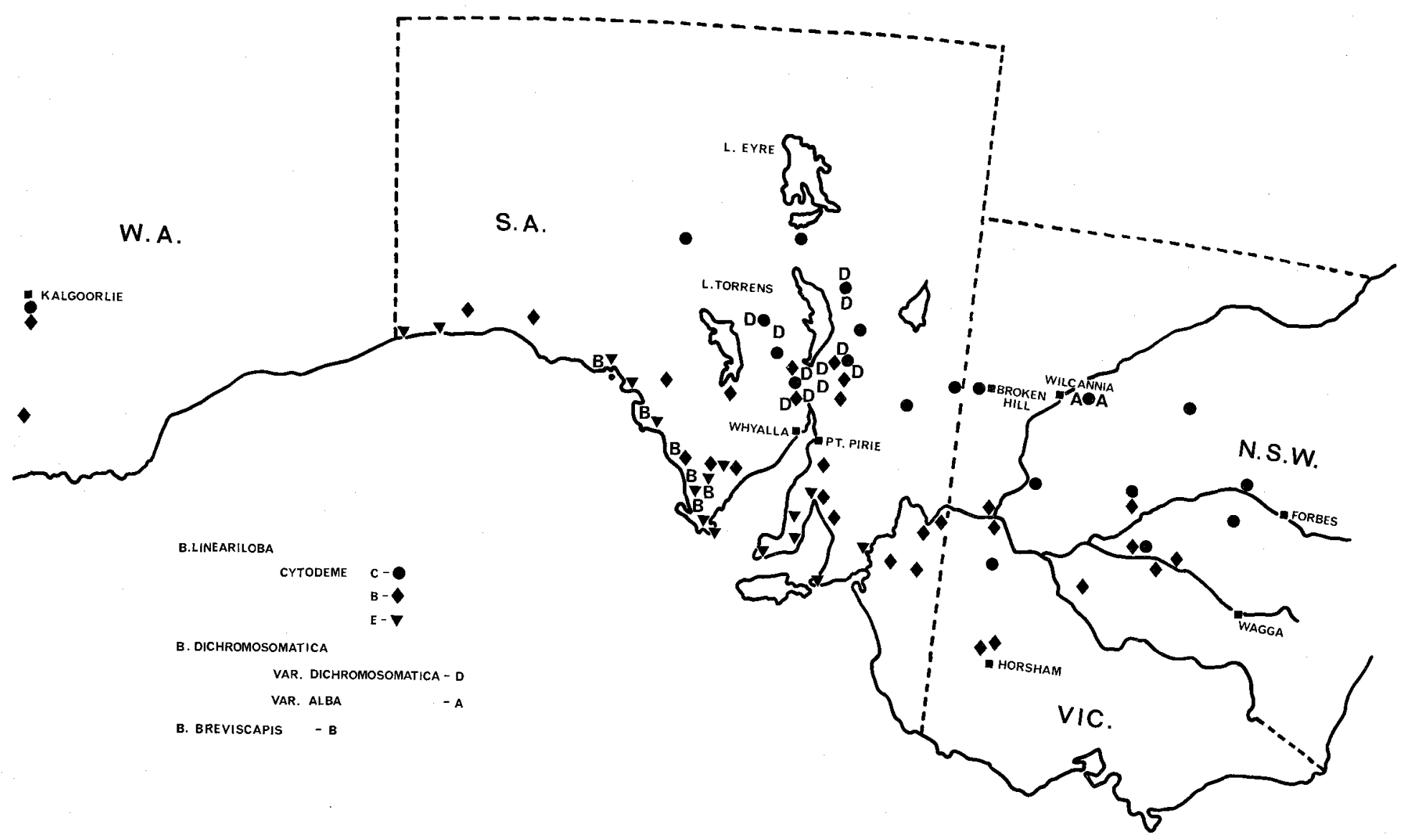

Map 1. The distribution of the species and cytodemes are determined from specimens in SYD. 


\section{Notes to the Key}

The only plants of $B$. dichromosomatica seen with reddish-purple margins on their involucral bracts were very large, and easily identified on the basis of habit and ligule length and colour. The smallest plants of $B$. lineariloba may be similar to the larger plants of $B$. breviscapis in terms of ligule and scape length. However, they are easily separated both in living plants and herbarium material. The smallest plants of $B$. lineariloba are exiguous in appearance with only one capitulum. The larger plants of $B$. breviscapis are more robust in appearance, and have several capitula.

\section{TAXONOMY}

1. Brachycome lineariloba ( $D C$.) Druce in Bot. Soc. Exch. Club Brit. Isles 4: 610 (1917); Davis in Proc. Linn. Soc. New South Wales 73: 167-169 (1948), pro parte.

BASIONYM: Steiroglossa lineariloba DC., Prodr. 6: 39 (1838).

LeCTOTYPE: Wet plains, Lachlan R., A. Cunningham, 29.vii.1817 (G-DC; microfiche seen).

TAXonomic Synonym: Brachycome pachyptera Turcz. in Bull. Soc. Imp. Naturalistes Moscou 24: 175 (1851).

Holotype: W.A., J. Drimmond 205 (KW). A photograph has been requested, but has not, as yet, been seen. There is a presumed isotype in MEL.

Habit: decumbent to ascending ephemeral to $150 \mathrm{~mm}$ high. Leaves usually basal, sometimes arising from lower part of scapes, up to $80 \mathrm{~cm}$ long, pinnatisect; segments $3-9$, up to $13 \mathrm{~mm}$ long, $1 \mathrm{~mm}$ broad, obtuse, occasionally with a short filiform proximal lobe. Scapes decumbent to ascending, glabrous, nearly naked, 10-200 $\mathrm{mm}$ long. Capitula 1-60, up to $13 \mathrm{~mm}$ diameter. Involucral bracts 8-13, $3.5-5 \mathrm{~mm}$ long, $2-4 \mathrm{~mm}$ broad, ovate to broadly obovate, obtuse; margins entire to laciniate, usually reddish-purple. Ligulate florets 6-14; ligules 1-6 mm long, $0.5-1.3 \mathrm{~mm}$ broad, white. Disc florets $10-35$. Receptacle $2-3 \mathrm{~mm}$ broad, $1.5-2 \mathrm{~mm}$ high, hemispherical, moderately to deeply pitted. Fruit broadly cuneate; body terete; wings turgid, demarcated from body by a groove, with silky glandular hairs up to $2 \mathrm{~mm}$ long on the margins. Pappus conspicuous, 1-1.5 mm long; bristles of unequal length, fused in bundles. Chromosome numbers: cytodeme B- $2 n=12$; $\mathrm{C}-2 n=16, \mathrm{E}-$ somatic no. $=10$.

Distribution: Western New South Wales, northwestern Victoria, southern South Australia, along the coast of the Great Australian Bight and the Kalgoorlie region of Western Australia.

Selected Specimens Examined: New South Wales: (Cytodeme C-2n=16). $58 \mathrm{~km}$ SE. of Lake Cargellico, 6795, 7.1970; $68 \mathrm{~km} \mathrm{NE}$. of Hay, 6772, 7.1970; $44 \mathrm{~km} \mathrm{~W}$. of Cobar, $4203,7.1969 ; 73 \mathrm{~km}$ E. of Wilcannia, 2095, 8.1968; $5 \mathrm{~km} \mathrm{~N}$. of Mossgiel, 6721, 7.1970; $11 \mathrm{~km}$ W. of Broken Hill 8006, 8.1971; $3 \mathrm{~km} \mathrm{E.} \mathrm{of} \mathrm{Pooncarie,} \mathrm{6703,} \mathrm{7.1970.}$

(Cytodeme B-2n=12). Willbriggie, 6804, 8.1970; $44 \mathrm{~km} \mathrm{W.} \mathrm{of} \mathrm{Darlington} \mathrm{Point,} \mathrm{6813,}$ $8.1970 ; 39 \mathrm{~km} \mathrm{NE}$. of Hay, $6770,7.1970 ; 11 \mathrm{~km} \mathrm{~S}$. of Mossgiel, $6726,7.1970 ; 5 \mathrm{~km} \mathrm{W.} \mathrm{of}$ Wentworth, 6859, 8.1970.

VICTORIA: (Cytodeme $\mathrm{C}-2 n=16$ ). $6 \mathrm{~km} \mathrm{~N}$. of Ouyen, $6846,8.1970$.

(Cytodeme B-2 $n=12$ ). $26 \mathrm{~km}$ E. of Warracknabeal, 6833, 8.1970; $20 \mathrm{~km}$ NE. of Nhil, $6837,8.1970 ; 6 \mathrm{~km} \mathrm{~S}$. of Nhil, $6836,8.1970 ; 3 \mathrm{~km} \mathrm{~S}$. of Red Cliffs, $6851,8.1970$. 
South Australia: (Cytodeme $\mathbf{C}-2 n=16$ ). Manna Hill, $8013,8.1971 ; 16 \mathrm{~km} \mathrm{E}$. of Blinman, 4800, 8.1969; $20 \mathrm{~km} \mathrm{~N}$. of Hawker, 6918, 8.1970; $14 \mathrm{~km} \mathrm{~N}$. of Leigh Ck., 4840, 8.1969; $50 \mathrm{~km} \mathrm{~W}$. of Marree, 4847, 8.1969; $16 \mathrm{~km} \mathrm{W.} \mathrm{of} \mathrm{Pimba,} 8068,8.1971 ; 150 \mathrm{~km} \mathrm{~N}$. of Kingoonya, $8088,8.1971$.

(Cytodeme B-2n=12). $23 \mathrm{~km}$ E. of Renmark, $6866,8.1970 ; 26 \mathrm{~km} \mathrm{~S}$. of Loxton, 6870 , $8.1970 ; 8 \mathrm{~km} \mathrm{E}$. of Lamaroo, $6876,8.1970 ; 2 \mathrm{~km} \mathrm{~W}$. of Karoonda, $6879,8.1970 ; 7 \mathrm{~km} \mathrm{~N}$. of Milendella, 6882, 8.1970; $14 \mathrm{~km} \mathrm{~N}$. of Carrieton, 6892, 8.1970; Cradock, 2127, 8.1968; $20 \mathrm{~km}$ N. of Hawker, 6919, 8.1970; Wilpena, 6909, 8.1970; $15 \mathrm{~km}$ NW. of Port Augusta, 236, 8.1967; $65 \mathrm{~km} \mathrm{~S}$. of Nonning, $7116,9.1971,16 \mathrm{~km} \mathrm{~W}$. of Rudall, $6948,8.1970 ; 46 \mathrm{~km} \mathrm{W.} \mathrm{of} \mathrm{Rudall,}$ $6967,8.1970 ; 26 \mathrm{~km}$ N. of Mt. Wedge, 7057, 8.1970; $60 \mathrm{~km} \mathrm{NE}$. of Wirrulla, 7104, 8.1970; $25 \mathrm{~km} \mathrm{~N}$. of Eyre Hwy, towards Cook, 7087, 8.1970.

(Cytodeme E-somatic no. = 10). $33 \mathrm{~km} \mathrm{E.} \mathrm{of} \mathrm{Murray} \mathrm{Bridge,} \mathrm{6880,} \mathrm{8.1970;} 1 \mathrm{~km} \mathrm{~N}$. of Murray Bridge, $6881,8.1970 ; 16 \mathrm{~km} \mathrm{~W}$. of Rudall, $6949,8.1970 ; 46 \mathrm{~km} \mathrm{~W}$. of Rudall, 6958 , $8.1970 ; 50 \mathrm{~km} \mathrm{~S}$. of Lock, 7007, 8.1970; Mt. Wedge, 4715, 8.1969; $15 \mathrm{~km} \mathrm{~N}$. of Mt. Hope, $7022,8.1970 ; 28 \mathrm{~km} \mathrm{NE}$. of Wirrulla, 7101, 8.1970; Laura Bay, 8878, 9.1972; Point Sinclair, S. of Penong, $8512,9.1971 ; 16 \mathrm{~km} \mathrm{~S}$. of Koonalda on coastal cliffs, 7094, 8.1970; Wilsons Bluff, E. of Eucla, 8497, 9.1971.

Western Australia: (Cytodeme $\mathbf{C}-2 n=16$ ). $3 \mathrm{~km} \mathrm{~N}$. of Kambalda, 8454, 9.1971.

(Cytodeme B-2n=12). $3 \mathrm{~km} \mathrm{~N}$. of Kambalda, $8456,9.1971 ; 45 \mathrm{~km}$ N. of Salmon Gums, $8436,9.1971$.

(Cytodeme E-somatic no. = 10). $20 \mathrm{~km} \mathrm{S.} \mathrm{of} \mathrm{Caiguna} \mathrm{Tank,} \mathrm{near} \mathrm{Point} \mathrm{Dover,} 8489$, 9.1971 .

\section{Brachycome dichromosomatica $C$. $R$. Carter, sp. nov.}

Scapi erecti $30-250 \mathrm{~mm}$ alti. Ligulae 5-12 $\mathrm{mm}$ longae pallide cyaneae vel albae. Bracteae involucri plerumque marginibus achromaticis.

Holotype: '15 km NW. of Port Augusta, S.A. (originally labelled "9 m N. of P.A.")', S. Smith-White and C. $R$. Carter 2339, 25.viii.1968 (NSW).

Habit: erect ephemeral, up to $250 \mathrm{~mm}$ high. Leaves basal or arising from the lower part of the scape, sometimes sheathing the lower part of the scape, up to $80 \mathrm{~mm}$ long, pinnatisect; segments 5-9 up to $15 \mathrm{~mm}$ long, $1 \mathrm{~mm}$ broad, obtuse, occasionally with a short filiform proximal lobe. Scapes glabrous, naked except for basal portion, erect, 30-250 $\mathrm{mm}$ long. Capitula 1-70, up to $13 \mathrm{~mm}$ diameter. Involucral bracts 8-13, 3.5-6 $\mathrm{mm}$ long, $1.5-4 \mathrm{~mm}$ broad, ovate to broadly obovate, obtuse; margins entire to laciniate, not usually pigmented, rarely reddish-purple. Ligulate florets 8-16; ligules 5-12 mm long. 1.5-4 mm broad, pale- to mid-blue or white. Disc florets up to 50 . Receptacle 2-3 $\mathrm{mm}$ broad, $1.5-2 \mathrm{~mm}$ high, hemispherical, moderately to deeply pitted. Fruit broad-cuneate, 3-5 mm long, 1.5-2 mm broad; body terete; wings turgid, demarcated from body by a groove, with silky glandular hairs up to $2 \mathrm{~mm}$ long on the margins. Pappus conspicuous, 1-1.5 mm long, bristles of unequal length fused in bundles. Chromosome number: $2 n=4+0-3$ large $\mathrm{B}$ chromosomes. At metaphase 1 of meiosis in plants with two $\mathrm{B}$ chromosomes three bivalents are regularly formed and such plants would appear to be $n=3$ (Carter and Smith-White, 1972).

\section{a. var. dichromosomatica.}

Ligules mid- to pale-blue, at least on the underside.

Distributron: Flinders Ranges and surrounding areas of South Australia. 
Selected Specimens Examined: South Australia: $21 \mathrm{~km} \mathrm{E.} \mathrm{of} \mathrm{Copley,} \mathrm{4816,} \mathrm{8.1969;}$ Brachina, 2241, 8.1968; $20 \mathrm{~km} \mathrm{~N}$. of Hawker, 6920, 8.1970; Cradock, 2126, 8.1968; $15 \mathrm{~km} \mathrm{~N}$. of Simmonston, 4764, 8.1969; $25 \mathrm{~km}$ E. of Quorn, 2330, 8.1973; $15 \mathrm{~km}$ NW. of Port Augusta, 2339, 8.1968; Uro Bluff, 4690, 8.1969; $8 \mathrm{~km} \mathrm{NW}$. of Pimba, 2427, 8.1968; $50 \mathrm{~km} \mathrm{W.} \mathrm{of} \mathrm{Port}$ Augusta, 4738, 8.1969.

\section{b. var. alba $C . R$. Carter, var. nov.}

Ligulae albae. Habitat in regione Wilcanniae, Nova Wallia Australis.

Holotype: 120 miles W. of Cobar ( $90 \mathrm{~km}$ E. of Wilcannia), New South Wales, S. SmithWhite and C. R. Carter 4247, 2.vii.1969 (NSW).

Ligules white.

Distribution: Region of Lake Poopeloe, E. of Wilcannia, N.S.W.

Selected Specimens Examined: New South Wales: "Volo" $70 \mathrm{~km}$ E. of Wilcannia, 4348 , $7.1969 ; 90 \mathrm{~km} \mathrm{E}$. of Wilcannia, 4213, 7.1969; $90 \mathrm{~km} \mathrm{E}$. of Wilcannia, 4267, 7.1969.

\section{Brachycome breviscapis $C . R$. Carter, sp. nov.}

Scapi decumbentes vel ascendentes 1-20 mm longi sed ille primigenus quam $10 \mathrm{~mm}$ brevior. Bracteae involucri marginibus plerumque purpurascentes. Ligulae quam $1 \mathrm{~mm}$ breviores. (NSW).

Holotype: $10 \mathrm{~km}$ S. of Elliston, S.A., S. Smith-White and C. R. Carter, 7042, viii.1970

Habit: stemless ephemeral up to $20 \mathrm{~mm}$ high. Leaves forming a basal rosette' up to $20 \mathrm{~mm}$ long, entire or pinnatisect, segments $1-4$, up to $5 \mathrm{~mm}$ long, $1 \mathrm{~mm}$ broad' obtuse, occasionally with a short filiform proximal lobe. Scapes glabrous, naked, 1-20 mm long, first-formed scape less than $10 \mathrm{~mm}$ long. Capitula 1-10, up to $6 \mathrm{~mm}$ diameter. Involucral bracts 8-9, 3-4 $\mathrm{mm}$ long, 1.5-4 $\mathrm{mm}$ broad, ovate to broadly obovate, obtuse; margins entire to laciniate, usually reddish-purple. Ligulate florets 4-10; ligules less than $1 \mathrm{~mm}$ long, less than $1 \mathrm{~mm}$ broad, white. Disc florets 5-20. Receptacle $1.5-2 \mathrm{~mm}$ broad, $1-1.5 \mathrm{~mm}$ high, hemispherical, moderately to deeply pitted. Fruit broad-cuneate, 1.5-2.5 $\mathrm{mm}$ long, 1-1.5 mm broad; body terete; wings turgid, demarcated from body by a groove, with silky glandular hairs up to $1 \mathrm{~mm}$ long on the margins. Pappus conspicuous, 1-1.5 $\mathrm{mm}$ long, bristles of unequal length and fused into bundles. Chromosome number $2 n=8$.

Distribution: Western coast of Eyre Peninsula, South Australia.

Selected Specimens Examined: South Australta: $50 \mathrm{~km} \mathrm{S.} \mathrm{of} \mathrm{Lock,} \mathrm{6993,} \mathrm{8.1970;}$ $15 \mathrm{~km} \mathrm{~N}$. of Mt. Hope, 7026, 8.1970; Mt. Wedge, 4722, 8.1969; $10 \mathrm{~km} \mathrm{S.} \mathrm{of} \mathrm{Elliston,} \mathrm{7042,}$ 8.1970; Laura Bay, 8877, 9.1972.

\section{ACKNOWLEDGEMENTS}

I am indebted to Professor R. C. Carolin for advice and the Latin diagnoses, also to Emeritus Professor S. Smith-White for advice and assistance. I thank the Director and staff of the National Herbarium of New South Wales for their cooperation. 


\section{LITERATURE CITED}

Carter, C. R., and Smith-White, S., 1972-The Cytology of Brachycome lineariloba. 3. Accessory chromosomes. Chromosoma (Berl.) 39: 361-379.

Carter, C. R., Smith-White, S., and Kyhos, D. W., 1974-The cytology of Brachycome lineariloba. 4. The ten chromosome quasidiploid. Chromosoma (Berl.) 44: 439-456.

Davis, G. L., 1948-A revision of the genus Brachycome. Proc. Linn. Soc. New South Wales. 73: 142-241.

Eichler, H., 1965-Supplement to J. M. Black's Flora of South Australia, ed. 2. Government Printer, Adelaide.

Gilmour, J. S. L., and Heslop-Harrison, J., 1954-The deme terminology and the units of microevolutionary change. Genetica (den Haag) 27: 147-161.

Kyhos, D. W., Carter, C. R. and Smith-White, S., 1977-The cytology of Brachycome lineariloba. 7. Meiosis in natural hybrids and race relationships. Chromosoma (Berl.) 65: 81-101.

Smith-White, S., 1968-Brachycome lineariloba. A species for experimental cytogenetics. Chromosoma (Berl.) 23: 359-364.

Smith-White, S., and Carter, C. R., 1970-The cytology of Brachycome lineariloba. 2. The chromosome species and their relationships. Chromosoma (Berl.) 30: 129-153.

Watanabe, K., Carter, C. R. and Smith-White, S., 1975-The cytology of Brachycome lineariloba. 5. Chromosome relationships and phylogeny of the race A cytodemes $(n=2)$. Chromosoma (Berl.) 52: 383-397. 